\title{
"The Sword in the Bishop's Hand": Father William Peter MacDonald, A Scottish Defender of the Catholic Faith in Upper Canada
}

\author{
Stewart D. Gill
}

Volume 50, numéro 2, 1983

Bilan de l'histoire religieuse au Canada

Canadian Catholic History: A survey

URI : https://id.erudit.org/iderudit/1007215ar

DOI : https://doi.org/10.7202/1007215ar

Aller au sommaire du numéro

Éditeur(s)

Les Éditions Historia Ecclesiæ Catholicæ Canadensis Inc.

ISSN

0318-6172 (imprimé)

1927-7067 (numérique)

Découvrir la revue

Citer cet article

Gill, S. D. (1983). "The Sword in the Bishop's Hand": Father William Peter MacDonald, A Scottish Defender of the Catholic Faith in Upper Canada. Sessions d'étude - Société canadienne d'histoire de l'Église catholique, 50(2), 437-452. https://doi.org/10.7202/1007215ar

Tous droits réservés @ Les Éditions Historia Ecclesiæ Catholicæ Canadensis Inc., 1983
Ce document est protégé par la loi sur le droit d'auteur. L'utilisation des services d'Érudit (y compris la reproduction) est assujettie à sa politique d'utilisation que vous pouvez consulter en ligne. 


\title{
"The Sword in the Bishop's Hand":
}

\section{Father William Peter MacDonald, A Scottish Defender of the Catholic Faith in Upper Canada *}

\author{
by Stewart D. GiLL \\ University of Guelph.
}

Ths Scottish contribution to the Catholic church in Canada has usually been associated with the Highlanders who settled in large numbers in Glengarry, in eastern Ontario, Prince Edward Island and eastern Nova Scotia. Most historians in writing about the Scottish influence or tradition in the Canadian church have concentrated by and large on the Glengarry settlement and its most eminent religious figure, Alexander Macdonell. ' Recently, Macdonell has come under attack because of his apparent Scottishness and lack of sympathy for Irish Catholics. ${ }^{2} \mathrm{He}$ is portrayed as a Tory with his roots sunk deep in the soil of Glengarry who had little contact with the urban based, reform minded Irish Catholics of Toronto.

\footnotetext{
* The author wishes to express his appreciation to the Rev. Dr. Mark Dilworth and Dr. Christine Johnson of the Scottish Catholic Archives for providing cups of coffee and much help in finding material and also the staff of the Archdiocese of Toronto Archives.

${ }^{1}$ William Perkins Bull, Fron Macdonell to McGuigan: The History of the Growth of the Roman Catholic Church in Upper Canada, Toronto, The Perkins Bull Foundation, 1939. R. MacLean, "The Highland Catholic Tradition in Canada", in W.S. Reid, ed., The Scottish Tradition in Canada, Toronto, McClelland and Stewart, 1976. Marianne McLean, "Peopling Glengarry County: The Scottish Origins of a Canadian Community", in Canadian Historical Association Historical Papers, 1982. J.E. Rea, Bishop Alexander Macdonell and the Politics of Upper Canada, Toronto, Ontario Historical Society, 1974. R. Sunter, "The Scottish Background to the immigration of Bishop Alexander Macdonell and the Glengarry Highlanders", Study Sessions of the Canadian Catholic Historical Association, 1973.

${ }^{2}$ Murray W. Nicholson, "Ecclesiastical Metropolitanism and the Evolution of the Catholic Archdiocese of Toronto", Histoire sociale / Social History, XV (May 1982), pp. 129-156.
} 
One of Macdonell's Scottish priests who played a prominent role in the establishment of the Catholic faith in Upper Canada, in the years of transition, while Scottish influence gave way to Irish, was William Peter MacDonald. After emigrating to British North America in 1826 he became the defender of the Catholic faith in the Upper Province and it is his role as "the sword in the Bishop's hand", or Macdonell's troubleshooter, that this paper will address. ${ }^{3}$ In 1828 he became vicargeneral to the Bishop in Kingston and two years later, in order to parry any attacks against the Church he commenced, with Macdonell, publication of a Catholic newspaper, The Catholic.

As editor of The Catholic he was ready to cross swords with any critics of the Church. The paper "being an exposition of the Catholic doctrine, designed to repel the calumnies and misrepresentations, which though so often refuted, have been constantly reiterated in the sectarian papers in the provinces." "4 As vicar-general the Bishop sent William Peter to support Father Patrick McDonagh against the revolt of William O'Grady. ${ }^{5}$ Later he was sent to Bytown to work among Irish lumberjacks and he ended his days as vicar-general to Bishop Michael Power in Toronto.

He was born on March 25, 1771 in the Parish of Eberlow, Banffshire. His parents were Thomas MacDonald and Ann Watt but apart from these facts little is known of his early life until he appeared as a student at Douay in France. He was raised in an area of Scotland where Catholicism had gained a stronghold during the eighteenth century under the patronage of the Gordon family. Concentrated in the north east, it has been estimated that sixty five percent of the Catholics of the Lowland Vicariate, in 1780, lived on the Duke of Gordon's estates, and that one third of all Lowland Catholics lived in the Enzie district of Banffshire. ${ }^{6}$

He would have completed his seminary training at Douay but for the intervention of the French Revolution which closed the College. He was initially dispatched to Scotland and then sent to the Scots College in Valladolid, Spain, in December 1794, where he was ordained on

\footnotetext{
${ }^{3}$ William Perkins Bull, From Macdonell to McGuigan.

${ }^{4}$ The Catholic, A Religious Weekly Periodical, October 22, 1830.

${ }^{5}$ On O'Grady see M.W. Nicholson, "The Catholic Church and the Irish in Victorian Toronto", vol. 1, Ph. D. Thesis, University of Guelph, 1980.

${ }^{6}$ Christine Johnson, Developments in the Roman Catholic Church in Scotland, 1789 1829, Edinburgh, John Donald Press, 1983, pp. 81-82.
} 
July $17,1798 .{ }^{7} \mathrm{He}$ was not regarded as being of sound character by the Spanish school as the author of the Register of Students speculated what had become of him:

Dec. 1794. Gulielmus MacDonald. Philosophian et theologiam corfecit, ordinatus est, et missionem petiit 17 Julii 1798. Ad tempus ibi remansit, sed postea aut illam deseriut, aut propter levitatem demissus est. ${ }^{8}$

On being ordained his first charge was the mission station of Deecastle situated on the River Dee. The station was small and poor, with few Catholics. Nevertheless, it was while in Deecastle that MacDonald found time to write his first work on the Catholic Church. Written in a mode that he was to follow in his Canadian writings, he first attacked the "inheritors" of the Reformation:

Ever since (the Reformation) we have had nothing but reformations of the reformation; but so many new schemes and opposite systems of religion, brought forward by a set of religious Boufoons (sic) who are daily appearing upon the stage, and exciting by their loud and outrageous declarations the admiration of the ignorant multitude. ${ }^{9}$

The remainder of the work is a theological treatise defending the doctrines of the Roman Catholic Church.

In 1801 he was moved to the seminary for the Lowlands at Aquhorties near Inverurie, Aberdeenshire. ${ }^{10}$ Aquhorties had been acquired in 1797 by Bishop George Hay. It opened in 1799 replacing the colleges closed by the Continental war. MacDonald entered the college only two years after its birth while it was still experiencing teething pains. As a professor he gained a reputation as a thorn in the side of his superior, Bishop Hay. He constantly bombarded Hay with letters outlining what he perceived to be wrong with the college and with requests to change its rules and regulations.

\footnotetext{
${ }^{7}$ Records of the Scots College at Douai, Rome, Madrid, Valladolid and Ratisbon, vol. 1, Aberdeen, Printed for the New Spalding Club, 1906.

${ }^{8}$ Ibid., p. 211.

${ }^{9}$ William Peter MacDonald, "Treatise on the Catholick Church" (handwritten copy). Scottish Catholic Archives (S.C.A.).

${ }^{10} \mathrm{Rev}$. William James Anderson, ed., "The College for the Lowland District of Scotland and Scalan and Aquhorties", Innes Review, XIV, 2, p. 170.
} 
In his demands he was unsuccessful and, apparently still discontented, in 1804 he was moved to Auchindoun near Dufftown. "Here he spent five years manifestly at conflict with his superiors. ${ }^{12}$ MacDonald was probably justified in his complaints as Dufftown was a poor mission station, ill furnished for the task it was built. It was however no worse than other charges in the Scottish mission. Portrayed in correspondence with his Bishop as a rebellious priest he soon attempted to remedy his impecuniosity by raising financial support outside of the Church. He provided accomodation for two boarders, and in 1809 wrote and published a volume of poetry which, despite vigorous efforts on his own part, would not sell. He heaped coals upon his head when, in 1806, he caused a scandal in his parish by dancing at a party and was on another occasion accused of being drunk at a funeral he was conducting. ${ }^{13}$

Most of his correspondence for the period at Auchindoun concerns his lack of money which was a disease common to Scottish priests. ${ }^{14}$ By 1807 he resolved that it would be no sin for him to leave the mission as he could not live on his allowance. He blamed Bishop Alexander Cameron for not assisting him financially and for the subsequent two years, between 1807 and 1809, the relationship between the two men grew worse. In 1809 he was transferred to Elgin where he wrote to the Reverend Charles Maxwell in Edinburgh:

I have been removed to Elgin, Bishop Cameron at our meeting, has, you will no doubt have heard, treated me in a most scurrilous, insulting and unchristian manner. It were no doubt to his own honour to make the one of his clergy who dares to disapprove most of what is blameable in his conduct, little in the eyes of his Brethern. I have reason to think this is not rash judgement. On this account I am just now hesitating about accepting a proffered mission in America, where I may work out my Salvation with peace and quietness. ${ }^{15}$

\footnotetext{
${ }^{11}$ William Peter MacDonald to the Right Rev. Dr. Alexander Cameron, March 31, 1804. S.C.A., Blair Letters (B.L..)

${ }^{12}$ MacDonald to the Bishops and Administrators of the Scottish Mission, July 31, 1804; MacDonald to Cameron, August? 1804, August 21, 1804, December 3, 1804. S.C.A., B.L.

${ }^{13}$ MacDonald to Cameron, December 8, 1806, S.C.A., B.L. MacDonald to Cameron, October 19, 1807, November 27, 1809. S.C.A., Preshome Letters (P.L.)

${ }^{14}$ C. Johnson, op. cit., pp. 132, 140.

${ }^{15}$ MacDonald to Rev. Charles Maxwell, September 18, 1809. S.C.A., P.L.
} 
The Offer of a placement in America was as a missionary at Miramichi, New Brunswick. He did not relish the idea of going so far from Scotland but, he insisted, if it meant an escape from poverty and a situation in which he was made out to be a liar by the Bishop then he would go. ${ }^{16}$ Cameron gave him permission to leave, probably thankful that he had ridded himself of a sore that continued to fester.

On leaving Elgin, in early 1810, he made his way to Aberdeen where he was distracted from the Miramichi mission by Father James Robertson, a priest employed by the British Government. Robertson offered him a large amount of money to go to London and join Government service. In a letter from Father Charles Gordon of Aberdeen to James Kyle of Aquhorties mention is made of an expected five thousand pounds that MacDonald would receive immediately to be followed by a pension of three hundred pounds for life; neither of which came to pass. ${ }^{17}$

For the following few years the whereabouts of MacDonald were a mystery to his friends in the Scottish mission. Many thought they had seen the last of him and that he had certainly relinquished any call to the priesthood. The priest at Auchinhalrig, George Matheson, wrote to Charles Maxwell in Edinburgh:

The poor Catholics in Miramishee (sic) are still anxious for a Scotch missionary to settle among them, Mr. Wm. once proposed going there, but I expect his missionary life is at an end... ${ }^{18}$

The years from 1810 until his departure for North America were spent in pursuits that were far removed from the duties of a priest in a small Scottish mission station. There have been numerous speculations as to what happened to MacDonald in this period much of which remains obscure. He did enter British government service and was involved in some capacity with an expedition to liberate Ferdinand VII of Spain from the clutches of Napoleon in 1810. He recounted in a letter to Charles Maxwell that he made friends with members of the Spanish and British nobility through taking part in such an episode. ${ }^{19}$

\footnotetext{
${ }^{16}$ MacDonald to Cameron, September 29, 1809. S.C.A., P.L.

${ }^{17}$ Charles Gordon to James Kyle, January 15, 1810. S.C.A., P.L.

${ }^{18}$ George Matheson to Maxwell, April 26, 1810. S.C.A., P.L.

${ }^{19}$ MacDonald to Maxwell, November 10, 1810. S.C.A., B.L.
} 
After a brief time in Spain as tutor to the son of the secretary to the Spanish Embassy at the British Court he found conditions not as favourable as he had hoped and obtained the aid of the British Embassy in Cadiz to return to London. ${ }^{20}$ From 1812 until 1819 most of his energy was directed towards raising a pension from the government. ${ }^{21}$ A letter from Kensington Palace in 1814 warned against him pushing too hard for recompense but recommended Canada as a suitable country for him to emigrate to, as it was "almost a Catholic country". ${ }^{22}$

From 1819 until 1826 it appears as if MacDonald lived in deep obscurity until "discovered" by Bishop Alexander Macdonell and invited to emigrate to Canada. There is the suggestion that he may have given up the priesthood while in London and may even have married. Alexander Cameron, Rector of the Scots College in Valladolid wrote to the Reverend James Machallie at Auchinhalrig: "Who is William MacDonald that has gone to Canada? If it be the poet, in what capacity does he go, and if he has got free on matrimony?" ${ }^{23}$ There is however no clear evidence for this speculation.

On arrival in Upper Canada he was appointed to the seminary at St. Raphael in Glengarry. In 1828 he wrote a letter to Bishop Alexander Paterson in Edinburgh during the course of which he suggested that the Canadian mission left much to be desired. ${ }^{24}$ One of his major concerns appeared to be a lack of fellow priests and he requested that Paterson should send "some zealous labourers into the Vineyard."

In contrast to his failures in Scotland, he advanced quickly up the colonial Catholic hierarchy, becoming Macdonell's vicar-general in Kingston in 1829. The cause of his rapid success may have been due to the money that he gave Macdonell. ${ }^{25}$ On the other hand, Macdonell may have been influenced by MacDonald being Scottish and having

\footnotetext{
${ }^{20}$ MacDonald to Matheson, July 27, 1811; MacDonald to Maxwell, January 27, 1811. S.C.A., B.L.

${ }^{21}$ Captain Alexander Cameron to MacDonald, August 15, 1812; Morris Forsyth to MacDonald, August 29, 1812; Louis-Philippe D'Orleans to MacDonald, November 6, 1813; Kensington Palace to MacDonald, March 31, 1814; Lt. General Wetherall for the Duke of Kent to MacDonald, May 3, 1819. Archives, Archdiocese of Toronto (A.T.A.), Macdonell Papers (M.P.)

${ }^{22}$ Kensington Palace to MacDonald, March 31, 1814. A.T.A., M.P.

${ }^{23}$ Cameron to Rev. James Machallie, April 19, 1828. S.C.A., B.L.

${ }^{24}$ MacDonald to Bishop Alexander Paterson, June 21, 1828. S.C.A., B.L.

${ }^{25}$ Bishop Alexander Macdonell to MacDonald, November 20, 1826. A.T.A., M.P.
} 
attended the same schools. In any case it appears as if an appointment as vicar-general carried little authority as the Bishop did not envisage the position as being autonomous in any way from himself. ${ }^{26}$

Nevertheless, Macdonell expressed the view that William Peter was someone in whom he could confide and assured him that he had confidence in him above all his fellow workers "to promote" the cause of Catholicism. ${ }^{27}$ The Bishop used MacDonald's name liberally in applications to Rome as he was known, "if not personally at least by character," 'by the rector of the Scotch College at the Holy See. ${ }^{28}$ (One can only hope that his character report came from other than Bishop Cameron of the Scottish mission.) James King, a Toronto Irish-Canadian journalist, who had a great enmity towards Macdonell, took it upon himself to attack MacDonald's character. ${ }^{29} \mathrm{He}$ decried him as having been on one occasion carried home drunk and naked in a cart from a party at Kingston's officers' mess and in such a state having attacked his superior. ${ }^{30}$ Macdonell came quickly to his Scottish friend's defence probably seeing the attack as much a slight against his own name and that of the Scots as against MacDonald. ${ }^{31}$ The Bishop insisted that MacDonald had never attacked him, "but on the contrary," he wrote, "I can attest with great truth and sincerity that on all occasions I received from you every respect and deference that was due to me, and often times more than I could wish." 32

Within six months of King's attack, MacDonald was making complaints, as he had in Scotland, to the lack of money. He wrote to Bishop Macdonell :

Your Lordship must be well convinced from my uniform conduct that I came not into your Diocese with the view of bettering my Fortune. Had I done so, would I have asked you for an Assistant, were none had been before; or accepted one at the high terms you were pleased to designate? Nor would I as I have done, laid out all I am nearly worth for what I imagined the furtherance

\footnotetext{
${ }^{26}$ M.W. Nicholson, "Ecclesiastical Metropolitanism," p. 135.

${ }^{27}$ Macdonell to MacDonald, July 11, 1832. A.T.A., M.P.

${ }^{28}$ Macdonell to MacDonald, August 30, 1832 (marked private and confidential). A.T.A., M.P.

${ }^{29}$ M.W. Nicholson, “Ecclesiastical Metropolitanism," p. 134.

${ }^{30}$ Macdonell to MacDonald, August 25, 1833. A.T.A., M.P.

${ }^{31}$ lbid.

${ }^{32}$ Ibid.
} 
of religion. Fortunate however it now begins to appear for me that (go where I may) I have still that left, which together with my mite of half pay, will put me above want, and the needful dependance on any unfeeling Superior. ${ }^{33}$

The Bishop in reply was displeased at rumours to the effect that William Peter was spreading stories as to how much be had done for Macdonell at his own expense. ${ }^{34}$ Friendship, it appeared, was not so much governed by nationality as by the size of the purse. The Bishop in correspondence with his vicar-general reminded him to keep his temper and that :

There is none of my clergy with whom I am half so anxious to help on good terms as with you, and I believe you will allow that I have incurred much ill will and jealousy by displacing others to settle you in Kingston and removed more than one clergyman, to please you, whom I sent to you as vicars. ${ }^{35}$

William O'Grady, an Irish priest, and Macdonell's vicar-general in Toronto, considered MacDonald's relationship with the Bishop as being central to the state of the Upper Canadian Diocese. The Irishman wrote to his scottish colleague in Kingston: "You have already made important sacrifices to promote the sacred cause of religion and yet it is to you alone that we must look to for the solution of that question, What is to be done?" 36 Both vicar-generals were aware that Macdonell in his old age could not administer his large diocese in the same manner as he had the old missionary church. ${ }^{37}$ In many of the Bishop's letters throughout the 1830's, especially those to MacDonald, there is reference to settling down with his own people in Glengarry. He particularly looked forward to spending his last years in the company of MacDonald. ${ }^{38}$ The latter it appears did not share the same affection for his Bishop since when asked by Bishop Gaulin to preach at Macdonell's funeral his first concern was to how much money would it cost him. ${ }^{39}$

\footnotetext{
${ }^{33}$ MacDonald to Macdonell, January 31,1834 . A.T.A., M.P.

${ }^{34}$ Macdonell to MacDonald, February 9, 1835. A.T.A., M.P.

${ }^{35}$ Macdonell to MacDonald, March 20, 1834. A.T.A., M.P.

${ }^{36}$ William O'Grady to MacDonald, no date, possibly July 1831 . A.T.A., M.P.

${ }^{37}$ M.W. Nicholson, "Ecclesiastical Metropolitanism, pp. 132-136.

${ }^{38}$ Macdonell to MacDonald, April 28, 1834; March 22, 1838. A.T.A., M.P.

${ }^{39}$ MacDonald to Bishop Gaulin, May 8, 1840. A.T.A.
} 
As in the poverty sticken Scottish mission, one of the major problems for the Bishop of Upper Canada was finance, raising money not only to build churches but also to pay for priests. This money was often obtained from Macdonell's Scottish friends, like William "Tiger" Dunlop and John Galt of the Canada Company. ${ }^{40}$ More often however he looked upon the "close fisted Scotsmen" in contrast to the "liberality of open hearted Irishmen." ${ }^{41}$ The Irish nevertheless presented the most difficult problem for the Bishop.

From the 1820s Macdonell failed to appreciate the significance in the growth of the Irish in Toronto and was therefore caught unprepared when his Irish clergy and laity rebelled under the leadership of William O'Grady. ${ }^{42}$ MacDonald had consistently advised Macdonell to recruit Irish priests for Toronto but even after the O'Grady case he was intent on withdrawing rather than increasing the number of clergy in the Toronto area. ${ }^{43}$ As in Scotland, where by 1829 Irish Catholics dominated Scottish Catholicism and changed it from a rural into an urban phenomenon, so the same happened in Upper Canada during the 1830s and, especially, the 1840s. Scottish priests in Canada merely reflected the views of their brothers in Scotland with regard to the Irish. Priests raised in the settled rural communities of north east Scotland were used to a well educated congregation whereas the Irish tended to be poor and itinerant. John Davidson, a priest at Greenock, reported to Bishop Cameron:

...the Irish Catholics hold, at least practically, part of the Presbyterian doctrine and seem to think that while they stick to the true faith they may safely neglect every other moral and religious duty which it prescribes. They are not only wretchedly ignorant of their duty, but seem perfectly careless about using the means of attaining the necessary knowledge of it. ${ }^{44}$

\footnotetext{
${ }^{40}$ Macdonell to MacDonald, June 13, 1827; July 7, 1827. A.T.A., M.P.

${ }^{41}$ Macdonell to MacDonald, November 6, 1829. A.T.A., M.P.

${ }^{42}$ See Macdonell Papers on O'Grady. For MacDonald's involvement see especially Macdonell to MacDonald, February 26, 1833; April 20, 1833; June 6, 1833; December 12, 1833; April 28, 1834. A.T.A., M.P.

${ }^{43}$ Macdonell to MacDonald, July 8, 1835 . A.T.A., M.P.

${ }^{44}$ John Davidson to Bishop Cameron, April 25, 1809. S.C.A., B.L. Quoted in C. Johnson, op. cit. , p. 137.
} 
Coming out of this Scottish background and having been a military chaplain during the suppression of the Irish Rebellion of 1798, Macdonell carried with him to Canada ideas of the Irish that were prejudicial to a harmonious relationship with them. He reflected Davidson's view, describing Irish Catholics as "grossly ignorant of the principles of their Religion, and of the discipline of the Catholic Church." 45 It was out of this concern over the ignorance of the Catholic population that MacDonald commenced publication of The Catholic to refute, as the Bishop wrote, "The professors of every other sect (who) are so industrious, active and united to seize upon every opportunity and avantage that present itself to propagate their errors and delusions..." 46

On October 22, 1830 the first edition of The Catholic appeared, printed at the Patriot Press in Kingston. The paper, subtitled "A religious Weekly Periodical", had three purposes: first, two negatives, the repudiation of what Protestants believed, and second, what Protestant journals wrote; third, a positive factor, the education of Catholics as to what their faith was. In fact most of the articles were borrowed from other journals.

Throughout every issue of the first volume there were articles attacking the different denominations within Protestantism. Britain's 'established' churches were frequently singled out for special mention:

The Presbyterian believes his Kirk of Scotland the only true church of Christ and Scotland the exclusively happy corner of the world, where it is established. A like belief is entertained by the Anglican of his parliamentary church, and of his country, exclusively blest with its establishment. But neither of them have any scripture for this belief... ${ }^{47}$

The authority of scripture and its interpretation became the centre of debate in every issue of the periodical.

MacDonald contributed most of the articles as editor and also wrote letters under the pseudonym of "Camillus." ${ }^{48}$ Under the latter he was

\footnotetext{
${ }^{45}$ Macdonell to MacDonald, July 8, 1831. A.T.A., M.P.

${ }^{46}$ Ibid.

${ }^{47}$ The Catholic, April 8, 1831, p. 189.

${ }^{48}$ For confirmation of pseudonym see Bishop William Fraser to MacDonald, June 28, 1831. A.T.A., M.P.
} 
particularly concerned about the methods adopted by the evangelical faiths to win over Catholics. He wrote:

You are not perhaps aware of the insidious methods resorted to, in this town by our would-be sole Orthodox and Evangelical gospellers, in order to decoy into their Sabbath schools and screaming conventicles the children of our poor Irish Catholics... The Catholics on such occasions, could be but the lookers on; as they are never seen to mingle in such evangelizing contests... ${ }^{49}$

Having thrown down the gauntlet to the Protestant press it was quickly picked up by The Christian Guardian. MacDonald wrote in a rebuttal to an attack by the latter paper:

In that heterogeneous of cant and fanaticism the Christian Guardian; that loathsome compost of mental ordure, raked together from all quarters to force a soil, which stubborn nature has refused; and render fertile an unconvertible caput mortum of sear and cauterized ignorance... ${ }^{50}$

Egerton Ryerson of The Christian Guardian was no less gentle in his attacks upon the writers of The Catholic. He assumed that the latter paper was the official organ of the Roman Catholic Church but was incredulous that "the members of that numerous and respectable body either cherish the feelings or entertain all sentiments, or approve of the denunciations of the Editors." ${ }^{51}$ The Anglican Christian Sentinel, under A.H. Burwell, and The Canadian Watchman were quick to join Ryerson in a scriptural condemnation of MacDonald's articles. ${ }^{52}$

The success of the paper did not lie in the hands of the Protestant press but with its Catholic subscribers. Agents were distributed throughout North America but, because of the theological nature of the contents, circulation appears to have been substantially limited to clergymen. ${ }^{53}$ Bishop William Fraser of Nova Scotia, a friend, formerly from the Scottish mission at Braemar, enjoyed The Catholic and encouraged his

\footnotetext{
${ }^{49}$ The Catholic, March 4, 1831.

${ }^{50}$ The Catholic, December 3, 1830.

${ }^{51}$ The Christian Guardian, April 16, 1831.

52 The Christian Sentinel, August 5, 1831; September 2, 1831. The Canadian Watchman, No. 31 .

${ }^{53}$ See list of agents in copies of The Catholic. Included agents from throughout Upper and Lower Canada and the United States, eg. Rev. Camusky of New York and Rev. Dr. Purcel, President of St. Mary's College, Emmet's Burgh, Maryland.
} 
clergy to subscribe. He was particularly delighted with the way in which MacDonald challenged the editors of The Canadian Watchman and The Christian Guardian. ${ }^{54}$ The Auxiliary Bishop of Quebec, JeanJacques Lartigue was also convinced of the necessity of the periodical for the success of the Catholic religion in Canada. ${ }^{55}$ It even continued to find success in the Lower Province one year after it had stopped being published. ${ }^{56}$ William O'Grady also wrote letters of encouragement to MacDonald as to the usefulness of his publication. ${ }^{57}$

The most inspiring letters of encouragement came not from Bishops or vicar-generals but two priests. The Reverend M. Lalor of St. Catherines wrote to MacDonald addressing him as one would a mentor. $\mathrm{He}$ informed him of the invaluableness of The Catholic to his ministry. $\mathrm{He}$ used it as a text book "in order to be able on the Sundays to explain the Mysteries of our Religion to a crowed church of Methodists." 58 From St. Andrews, New Brunswick, the Reverend T. O'Meara wrote that The Catholic provided the substance for his sermons and exhortations. ${ }^{59}$

By October 1831 the paper was bankrupt because of a lack of subscribers, not surprising perhaps when one considers the nature of the articles and the audience it was addressing. Within a few years, however, Macdonell offered MacDonald the opportunity to recommence publication of a journal "conducive to the interests of the Catholic Religion." 60 The Bishop pleaded poverty and an inability to pay for the re-establishment of the press but demanded complete control of the paper as a requirement of his support. He was concerned that his vicar-general's approach "may appear to injure rather than benefit the cause." 61 Perhaps he had a greater fear of alienating himself from his Presbyterian friends.

MacDonald attempted to revive The Catholic with the assistance of Bishop Gaulin but the subscriptions raised were too small to support

\footnotetext{
${ }^{54}$ Bishop Fraser to MacDonald, June 28, 1831. A.T.A., M.P.

55 Bishop Jean-Jacques Lartigue to MacDonald, January 16, 1831. A.T.A., M.P.

${ }^{56}$ Macdonell to MacDonald, November 14, 1833. A.T.A., M.P.

${ }^{57}$ O'Grady to MacDonald, May 17, 1831. A.T.A., M.P.

${ }^{58}$ Rev. M. Lalor to MacDonald, February 23, 1833. A.T.A., M.P.

${ }^{59}$ Rev. T. O'Meara to MacDonald, June 19, 1833. A.T.A., M.P.

${ }^{60}$ Macdonell to MacDonald, March 10, 1835; February 5, 1838. A.T.A., M.P.

${ }^{61}$ MacDonald to Captain MacMillan, January 16, 1838. A.T.A., M.P.
} 
the venture. ${ }^{62} \mathrm{He}$ became disgusted at the apathy shown by Catholics towards having their own paper. They appeared to have no appreciation of the power of the press and while Protestants had papers in every township, MacDonald wrote to Bishop Gaulin, the Catholics could not even unite to support one. "How different," he continued, "is the case in the United States; where every Bishop has his press; and where therefore our holy Religion is bearing down all before it..." 63

The first edition of volume two did not appear until September 15, 1841 and was printed in Hamilton. The aim of the paper was similar to the first volume and was set out in the opening editorial:

In offering once more to the Public our Weekly Periodical, The Catholic, we wish it to be understood that it is not our intention to make it a work of polemical discussion or religious disputation; except when forced, in self defence, to repel the wanton and unmerited attacks of others - to expose the ignorant or wilful misrepresentations of the Catholic doctrine; and, when calumniated, to set ourselves right in the general estimation. ${ }^{64}$

Within six months of the first issue the editor was once again complaining to Bishop Gaulin of the Catholic population's failure to support one paper against the Protestant journals. ${ }^{65}$ In 1842, however, Bishop Michael Power, on his accession, took over the paper to use as his personal organ. Although still under the editorship of MacDonald, there were articles of a more popular nature and news from the "old country."

William Fraser once again took out a subscription for himself and the priests in his diocese while acting as agent for the paper in the Maritimes. ${ }^{66}$ The Maritimers' allegiance to it appears to have been based upon a personal loyalty to MacDonald. When it was sold in 1844 and became The Liberal Fraser wrote to MacDonald expressing that since the paper was no longer under his management the Maritime subscribers requested that they be withdrawn from the subscription list of the new paper. ${ }^{67}$

\footnotetext{
${ }^{62}$ MacDonald to Bishop Gaulin, December 7, 1839; January 21, 1840. A.T.A., M.P.

${ }^{63}$ MacDonald to Bishop Gaulin, January 21,1840 . A.T.A., M.P.

${ }^{64}$ The Catholic, September 15, 1841.

${ }^{65}$ MacDonald to Gaulin, February 23, 1842. A.T.A.

${ }^{66}$ Bishop Fraser to MacDonald, July 19, 1842; December 23, 1842. A.T.A.

${ }^{67}$ Fraser to MacDonald, August 2, 1844. A.T.A.
} 
In 1844 MacDonald moved from Hamilton to Toronto and new responsibilities as vicar-general to Bishop Power and Dean at St. Michael's Palace. His last few years were devoted to building St. Michael's Cathedral, and in his will he bequeathed all his possessions to the building fund. Appropriately, when he died on Good Friday, April 2, 1847 he was buried in the unfinished Cathedral.

MacDonald had been involved in the Scottish mission during the early years of the nineteenth century when it was stili by and iarge dependant upon the benevolence of Catholic landlords. In the period 1680 to 1800 the Roman Catholic population of Scotland decreased from fifty to thirty thousand. ${ }^{68}$ The reduction was caused partly by persecution following the Whig Revolution of 1688, the failure of the 1715 and 1745 rebellions and, the most important reason usually given, the Highland Clearances. All of these factors led to emigration overseas, especially to Britain's North American colonies.

After the Union of the Scottish and English Parliaments in 1707 all of England's colonies were opened up for exploitation by the Scots. Following the American Revolution, British North America became increasingly attractive to British emigrants and in particular, the Scots. In religious terms, Scottish Protestant clergy discovered that Canada provided a means of employment until a better charge could be obtained in Britain, and the Catholics found greater toleration and freedom through the French presence. When Alexander Macdonell arrived in Upper Canada in 1804 there were only two areas populated by Catholics - the Scots of Glengarry and the French at Sandwich and he was often the only priest serving the whole of Upper Canada. ${ }^{69}$

MacDonald paralleled the career of Macdonell both having been educated on the Continent. Discontented with the Scottish Catholic hierarchy the former was transferred around north east Scotland until he found, like Macdonell, some satisfaction in government service. In 1826, having been called by Macdonell to serve in Canada he found to his disappointment that the colonial mission was as impecunious as the Scottish and often depended upon the Bishop's contacts with members

\footnotetext{
${ }^{68}$ James Darragh, "The Catholic Population of Scotland Since the Year 1680", Innes Review, IV, p. 51.

${ }^{69}$ M.W. Nicholson, “'Ecclesiastical Metropolitanism,’” p. 131.
} 
of the Family Compact. While the Canadian Church was as much governed by the purse as the Scottish, nevertheless there was room for advancement in the colony. He quickly became the Bishop's right hand and was given responsibility for publication of a Catholic newspaper.

Dr. Murray Nicholson has portrayed Macdonell's choice of MacDonald over O'Grady to be editor as Scottish discrimination against the Irish by creating a paper that "was Tory in politics and lacking in Irish content." ${ }^{70}$ Not only was there no Irish content there was no Scottish. The paper was by and large a theological work with an absence of political or ethnic content. It was printed by Thomas Dalton, publisher of the Patriot and apologist for the Family Compact, and there were a few political comments which took a Tory line as, for example, an appeal to the loyalty of home grown religions as opposed to American Methodism. ${ }^{71}$ Politics was, however, not the main thrust of the paper. Macdonell expressed concern that the constant attacks upon the protestant press would injure the success of the paper. While the Bishop probably had in mind his own friendship with Protestant and government leaders being jeopardised by slanderous articles, its failure can probably be traced to the contents which were aimed at an educated clerical and lay audience and not directed to win the affections of an ethnic group.

Alexander Macdonell has become for most historians the stereotype of the Scottish Roman Catholic in Upper Canada. ${ }^{72}$ The Reverend William Peter MacDonald has been described by William Perkins Bull in his history of the Church in Upper Canada as "the sword in the Bishop's hand". ${ }^{73}$ Seen in such a light, MacDonald could be described merely as an appendage of the Bishop. He had been however a thorn in the flesh of the Scottish Church and while he did become a sword in the hands of the Canadian, as far as publication of The Catholic was concerned, the sword was double edged, as quick to attack the faults of the Bishop as the Protestant Faith.

\footnotetext{
${ }^{70}$ M.W. Nicholson, “The Catholic Church and the Irish," p. 31.

${ }^{71}$ The Catholic, April 8, 1831.

${ }^{72}$ See note 1.

${ }^{73}$ W.P. Bull, From Macdonell to McGuigan.
} 
While corresponding with old friends from the Scottish Church, like Bishop Fraser and Bishop James Kyle, MacDonald did not have the same affection for the Scots in Upper Canada as his Bishop. ${ }^{74}$ Unlike Macdonell he had no constituency among the Scots of Glengarry. Professor R. MacLean has written of the Catholic Highlanders in Glengarry that they shared basic traditions with the Presbyterians. ${ }^{75}$ According to MacLean, their common heritage that they rediscovered on the frontier of Upper Canada forced them to forget their native animosity and encouraged greater tolerance. ${ }^{76}$ Macdonell was at the forefront of this movement while his vicar-general, through the medium of The Catholic publically attacked and antagonised the Protestant press.

In looking at a Scottish tradition in the Roman Catholic Churches in Canada it is important to bear several facts in mind. First, Macdonell, portrayed as the archetype Scottish priest, was by the 1830s trying to maintain control on the basis of Scottish ethnicity with the appointment of priests like MacDonald, when the majority of Catholic adherents were Irish. Second, not all Scottish priests were like their Bishop, as being Scottish did not imply an affinity for the Scots. MacDonald having spent a major part of his life on the Continent or in England demonstrated no particular affection for the Scots in Upper Canada. Third, after the 1840s it was impossible to speak of Scottish dominance anywhere in the Church except in Glengarry.

MacDonald's influence in the Catholic Church in Canada was to help in a transition period between Bishop Macdonell and a rural based mission and the formation of an urban based, reform minded institution which saw the necessity for newspapers as a mean of communication. MacDonald demonstrated a belief in the future and power of the press in the prospectus for The Catholic. He wrote: "Quod semper, quod ubique, quod ad omnibus creditum est" (What always, and every where and by all is believed). The Scottish period in the Roman Catholic Church in Upper Canada, although short lived, was at the very base of the heritage of Catholicism in Canada. It was not entirely a conservative and inhibiting factor as some would suggest in looking at Macdonell as there were men like MacDonald who while building on the past looked forward to the faith of future generations.

\footnotetext{
${ }^{74}$ MacDonald to Bishop Alexander Paterson, June 21, 1828. S.C.A. Also letters to Fraser and Kyle in the S.C.A. and A.T.A.

${ }^{75}$ R. MacLean, “The Highland Catholic Tradition,", p. 95.

${ }^{76}$ Ibid.
} 